\title{
Sobre el escandaloso «Llibre de les bèsties» de Ramón Llull y su audiencia
}

\author{
JULIA BUTIÑÁ JIMÉNEZ \\ Depto. de Filología Clásica. UNED
}

\begin{abstract}
RESUMEN
Las referencias a los apostólicos por parte de Ramón Llull permiten plantear el Llibre de les bèsties como una crítica a los miembros de aquella secta, quietistas y antijerárquicos. Ello explicaría la inserción natural de este libro como un capítulo más del Llibre de meravelles, que anteriormente parecia una inclusión forzada. A su vez, contribuiria a interpretar su estridente inmoralidad, la cual resalta que hay que actuar aprovechando todos los recursos, de acuerdo con la ordenación de la Creación, como hacen los animales que sirven de ejemplo, activos y fieles a su rey.
\end{abstract}

\section{PALABRAS CLAVE \\ Literatura Catalana, Literatura Comparada, Humanismo, Literatura Medieval, Literaturas hispánicas, Bestiarios, Ramón Llull, Lulismo.}

\begin{abstract}
The references of Ramon Llull to the apostolics allows us to see the Llibre de les bèsties as a criticism of the members of that sect. This explains the natural inclusion of this book just like a chapter of the Llibre de meravelles, which otherwise seemed a forced insertion. It also contributes to the interpretation of his strident immorality, which justifies itself because is necessary to act. That is, to act using all the resources in accordance with the order of Creation, as do the animals that are exemplars, actives and loyals to his king.
\end{abstract}

\section{KEY WORDS}

Catalan Literature, Comparative Literature, Humanisme, Literatures Hispanics, Literature Medieval, Bestiary, Ramon Llull, Llullism

Realmente es sorprendente este libro, injertado en el Llibre de meravelles luliano; pero, a pesar de que se ha resaltado su originalidad, sorprende que no haya sorprendido aún más. De todos modos no debe andar muy desencaminada esta actitud cuando era la que pretendía conseguir el autor en su lector, según se 
desprende del comienzo de la obra en la que se incluye ${ }^{\prime} y$, consiguientemente, asegura en el epílogo ${ }^{2}$.

En este trabajo, un detalle del prólogo que afecta a su cronología nos lleva a proponer una nueva audiencia para este libro. Llull escribe el Llibre de meravelles alrededor de 1289, durante su estancia en París ${ }^{3}$ (Batllori, M., 1993: 166-168); como término post quem se da el año 1286, en que Honorio IV condena la secta de los apostólicos, la cual se critica en el capítulo $13 \mathrm{del}$ libro VIII ${ }^{4}$. Ahora bien, como en el capítulo 76 del Blanquerna -que es de 1283 - parece alabarlos ${ }^{5}$, se ha creido que el Llibre de les bèsties -que no sólo tiene vida propia sino que está incrustado materialmente en la obra ${ }^{6}$ - debia tenerlo confeccionado antes de

Empieza el prólogo, a modo narrativo, contando que un hombre "fortment se meravellava de les gents d'aquest món" y encomienda a su hijo: "Ve per lo món, e meravella't dels hómens", Llibre de meravelles, Barcelona, ed. 62, 1980, pág. 19 (edición que seguiremos para la obra en general, asi como también para el Llibre de les bèsties en particular). Esta misión, la de maravillarse o sorprenderse, es, pues, la que pretende aqui comunicar a los hombres y la que emplea como metodologia con fines doctrinales.

2. Si la obra arranca con el encargo de un hombre a su hijo, Félix - nombre que también designa al Llibre de meravelles , la tarea de ir por el mundo sorprendiéndose, concluye, al morir éste, cuando un monje que ha entrado en su dinámica asume continuar aquel oficio cual un segundo Félix. Una anécdota del cierre ilustra que ha asumido bien la función encomendada, pues el Félix moribundo se sorprende ante el hecho de tener que morirse, por considerar que el encargo de irse maravillando todavia podía darle mucho de si.

Cabe añadir que los prólogos y epilogos de las obras catalanas de Liull acostumbran a sintetizar muy intensamente el contenido principal de las mismas (BUTiNA, J., "Ramon Llull: Llibre del gentil e los tres savis. Llibre de meravelles, Llibre de Santa Maria: pròlegs i epilegs de Ramon Llull», en Lectures de literatura catalana a Madrid. Quinze lliçons del seminari al Centre Cultural Blanquerna (1997-2002), "Textos i documents", 25, Barcelona, Generalitat de Catalunya, 2003, págs. 149-172).

3 La referencia a hallarse el padre de Félix en una tierra extraña no implica necesariamente una alusión biográfica al autor, puesto que un libro de fuerte carga platónica como es éste puede estar aludiendo al hecho de encontrarse fuera de su mundo originario; aunque parece que su redacción coincide con aquella estancia parisina.

4 Sin embargo. como veremos, el efecto de la presencia de los dos varones apostólicos tiene también un filo positivo por recordar la santa vida apostólica, representada en sus cabellos y trajes; si bien aquí predomina lo negativo por no hacer éstos lo que los apóstoles hacian. La ubicación de su rechazo es idónea. pues el libro VIII trata del placer de ver, donde se dice que, si es agradable ver las cosas corporales bellas, más lo es ver las espirituales, y ahí se tilda a los apostólicos de hipócritas por no ser lo que figuran, siendo censurados por no comportarse de acuerdo con lo que significan.

Sin embargo, como veremos, la frase reconocida como alabanza es una recomendación para que hagan concordar su nombre con sus actos, dado que ese oficio conlleva una alta exigencia; por lo que, al igual que los apóstoles, deben ir por el mundo reprendiendo los vicios humanos, sin temor a peligros ni esfuerzos. Por ello, el canónigo (la voz del autor) les habla de modo condicionado y les dice que "si ells volien ésser en lorde dels Apóstols...". Es, pues, una exhortación al activismo pero que no excluye el carácter premonitorio; de modo que la alabanza del Blanquerna es más utópica que real. Ello aproxima la actitud luliana en ambas obras, puesto que en las dos se da una valoración ambivalente, ya que si en una no se censura la actitud apostólica que representa tan digno nombre sino a quienes no la cumplen, en la otra se condiciona el pertenecer a esta orden a los hechos. $Y$ en ambos casos se requiere la concordancia entre la imagen, el nombre y los actos, denunciándose el fallo de esto último en el Llibre de meravelles.

- El Llibre desentona tanto por la estructura como por el estilo, aunque está encajado como un libro más, el 7, el cual, según el enfoque enciclopédico de la obra, corresponde al tema de los animales. Pero hay que recordar que por encima de su carácter enciclopédico se trata de una obra didáctico-moral; o sea, es una enciclopedia sui generis, en la que, aunque mantiene un planteamiento cientifico y universal, el sistema de preguntas y respuestas tradicional se torna anovelado a fin de una mayor efectividad, ficción que hace factible que una secuencia desarrolle otra internamente con fines especificos. 
aquella fecha, porque en su prólogo parece encomiarse «la orde dels apòstols", cosa que lo acercaria al juicio del Blanquerna. Esta referencia laudatoria, sin embargo, se consideraba un fallo literario por estar ya condenados los apostólicos cuando escribe el Llibre de meravelles; o sea que la fugaz aparición de éstos se habia juzgado, además de marginal o anecdótica, errónea.

Ahora bien, vamos a observar unos hechos que alteran este estado de cosas y hacen poner a revisión que sea un lapsus de Llull el nexo con que intercala el libro $^{7}$, a raiz de lo cual cobran relieve dichos varones.

He aquí los tres textos citados, que atañen directamente a los apostólicos:

I: "Orde d'apóstol és sobirà a tots ordes. E qui és en orde d'apóstol, no deu dubtar mort. e deu anar mostrar la via saludable als infeels qui són en error: $e$ als crestians qui són en pecat deu dar doctrina de santa vida, per obra e per preicació. Aital hiom qui sia en orde d'apóstol. no deu cessar de pregar e de fer bones obres a tot son poder. (...) e ab ells ensems plorà llongament, e dix estes paraules: 'Ai, sènyer Déus Jesucrist!: ion és la santa fervor e devoció qui ésser solia en los apostols, qui en vós amar e coneixer no dubtaven a sostenir treball ni mort? Bell senyor Déus, placia a vos que en breu venga temps en qui es complesca la santa vida que és significada en la figura de la vida d'aquests hòmens'", Llibre de les bèsties, págs. 113-114

\begin{abstract}
II: "Mas car l'ermità e Fèlix consideraven l'estament en què aquells homens estan, los quals s'apellen de lorde dels Apòstols, e aquells no preiquen ne fan ço que els apostols faien, adoncs hagren l'ermità e Fèlix desplaser en veser aquells dos hómens, per ço car llurs obres no es convenien ab ihabit que portaven. Lermità e Fèlix ploraren llongament, e digueren ensems aquestes paraules: "Ai, hipocresia! Per què no mors! ;A, bellea d'hàbit e falsa entenció! ¿per qué us ajustats en negun hom? A Déu! Trametets homens plasents a veser, e per hàbit corporal e esperital, per tal que sia vist que vós havets molts hòmens que en honrar e amar vós. són bons precuradors e ardits lloadors", Llibre de meravelles, pág. 173
\end{abstract}

III: "Lo canonge llur demanà de qual orde eren, e ells Ii respongueren dients que eren de l'orde dels Apòstols; e lo canonge respós dient que lo seu ofici e lo nom de llur orde se convenien. Los frares qui s'apellen de l'orde dels Apóstols " digueren que els esponés la concordança que deia, e lo canonge llur dix que apostol deu ésser perseguit per injusticia; e per aço. si ells volien ésser en l'orde dels Apóstols, covenia que en les ciutatse en les viles e els castells per on passarien preicassen la paraula de Déu, e que reprenessen los homens dels pecats que els veurien fer, e que no dubtassen mort ni treballs, e que la te catolica anassen preicar als infeels per co que mills fossen semblants als apóstols", Blanquerna, pàg. 206.

Cabe observar, por otro lado, que el uso de la ficción por parte de Llull no responde a una lógica exacta sino que está supeditado a sus intereses morales; asi, vemos que el mismo ejemplo de la diadema de la hija del rey y la serpiente se repite en el mismo capitulo 4 con los mismos elementos pero con finales contradictorios (ed. cit., págs. 124 y 127); no obstante, no se ha desprendido de ello el aprovechamiento de redacciones anteriores o despistes del autor, como se ha hecho con este prólogo.

La irrupción del libro, que tiene lugar por medio del prólogo -en el que se anuncia una gran convocatoria de los animales para elegir rey-, no sólo va a alterar la sistemática de enseñanza, sino que va a ocasionar una curiosa descolocación de los elementos literarios, porque si en los demás capitulos se cuenta, además del plano del lector, con los del autor, el protagonista y los personajes -estos dos úitimos, como suele ocurrir en la narrativa, en el mismo estadio-, a partir de este prólogo el protagonista se traslada junto al autor, frente a los personajes. Hábil truco literario que _como en el cine de Almudóvar-afecta a la realidad-ficción, pero sobre todo hace destacar que unos personajes - los dos apostólicosse van a inhibir del espectáculo que aquellos dos elementos - autor y protagonista - van a presenciar: con lo cual, los apostólicos quedan fuera de juego.

Llinarès da relieve al prólogo y observa que habla de Félix y accidentalmente de los animales, pero quien lo protagoniza es el par de apostólicos, que desaparecen con el mismo prólogo (ed. cit. pág. 19). Gracias a esa técnica, el autor habría conseguido hacer pasar desapercibido un elemento insólito e innecesario desde la trama literaria - Ios dos apostólicos-.- cuando es pieza que protagoniza el pasaje. 
Observamos en primer lugar que las referencias I y III no son totalmente halagüeñas. En el Llibre de les bèsties, Félix se exclama porque ha desaparecido el fervor de los apóstoles, dice que quien esté en esta orden no debe cesar de rezar y de hacer buenas obras con todas sus fuerzas, así como desea que se cumpla "la santa vida que és significada ${ }^{8}$ en la figura de la vida d'aquests hòmens"; es decir, lo que pronuncia es en realidad un deseo y una exhortación, pero no defiende en ningún caso que esos apostólicos lo estén llevando a cabo, lo cual convierte incluso su exclamación en un reproche rayano en la ironia hacia esos anodinos personajes que no intervienen más y ostentosamente dejan de actuar. De un modo parecido, en el Blanquerna se aprecia un tono y sesgo de amonestación, que impide calificarse de pura loa. Por otro lado hay que observar que la reprobación de II se funda en la omisión, en que los apostólicos no predican ni actúan, como hacían los apóstoles. Por ello, dado que el juicio sobre los apostólicos no es tan simple, aunque sí homogéneo por su ambivalencia, hay que replantearse la cuestión; aunque no lo haremos a efectos cronológicos - como ha hecho la crítica - sino de la audiencia.

El advertir en las referencias consideradas laudatorias signos de reproche se agudiza en el primer caso si se tiene en cuenta que es el pórtico de un libro cuya ejemplaridad deriva principalmente de la exaltación del activismo; libro, por otro lado, que encabezan unos individuos que son propensos al quietismo (en concreto, antes de 1291 los apostoli se caracterizaron por el carácter místico-pacífico, Lubac, $H$. de, 1989: 113). Y sobre todo induce a verlo así el que uno de los rasgos que definen a Llull es la defensa de la vida activa, como quedó bien estampado en su biografía (Vida coetània).

La indiscutible ambigüedad de las referencias quizás pudiera hallar explicación en la proximidad de Llull para con la corriente joaquinita - franciscanos espiritualistas descendientes de Joaquín de Fiore-, muchos de cuyos miembros formaron sectas rechazadas o perseguidas por la ortodoxia ${ }^{9}$. Es decir, Llull no arremetería gustoso contra una orden que se dedicaba a cumplir a rajatabla los preceptos

${ }^{8}$ El concepto de significación, frecuente en las obras lulianas, hay que entenderlo como 'representación' o revelación de algo interno u oculto; así, los usa como sinónimos en este prólogo. Según la definición que da Llull del mismo: "Significació es ens per lo qual secret es revelat, per so car significació ateyn aquelles coses que intren al subjet e yxen del subjet. (...) Significació es revelació dels secrets ab senyal de les coses demostradores". Diccionari de definicions lul lianes. Dictionary of lullian definitions, A. Bonner y M. I. Ripoll Perello, "Blanquerna" 2, Universidad de Barcelona-Universidad de las Islas Baleares 2002, pág. 271.

${ }^{9}$ La secta encabezada por Gherardo Segarelli es la más próxima a Llull y la condena de la Ordo Apostolorum - que designa por antonomasia a los denominados como apostólicos--, fundada por aquél, fue reiterada hasta su quema como hereje en 1300; según la Enciclopedia Italiana, sus partidarios probablemente se difundieron, desde Italia, a España y Alemania (Apostolici y Segarelli, en los vols. Ill y XXXI, respectivamente pp. 293 y 706, Istituto della Enciclopedia Italiana, Roma 1950). Señalamos de todos modos por afectar a la cronologia de la condena, la cual ha influido en la datación del Llibre de meravelles, que hubo conminaciones anteriores ( $P$. Tineo anota la del concilio de Lyon, en 1274 , en "Apostólicos", Gran Enciclopedia Rialp, II, ed. Rialp, 1971, Madrid, pág. 522); y también, que las corrientes que se fundan en la imitación de las costumbres de los apóstoles o apostólicas aparecieron ya en la Iglesia primitiva, si bien no hay noticia de ellas hasta el Panarion de san Epifanio, en el siglo fv. 
evangélicos (al pie de la letra: tenían una sola túnica, por ejemplo), cuando no cejaba de acusar valientemente a la Iglesia por lo contrario (interés por las riquezas frente al desinterés de los apostóles). Ahora bien, se consideraron heréticos sobre todo por no reconocer la autoridad eclesiástica, mientras que Llull no fue nunca antijerárquico; por lo que, de acuerdo con la condena papal, debia darles una lección. Como puede serlo este libro ${ }^{10}$.

Además, es favorable a la defensa de una inserción no sólo natural y correcta ${ }^{11}$ sino plenamente oportuna el considerar el paralelismo con la otra pseudo-novela $^{12}$ luliana, Blanquerna, la cual incluye asimismo con vida propia un libro fundamental, en este caso -inversamente- para la mística: el Llibre d'amic $e$ Amat ${ }^{13}$; libro que también se aviene perfectamente a la obra en la que se integra y en cuyo prólogo o nexo de inserción se dan datos esenciales de la misma, como la inspiración en la espiritualidad sufí. O sea que la inclusión del de les Bèsties dentro del de les Meravelles puede deberse también a la eficacia de formar parte de otra obra mayor, a la que, a pesar de la aparente discordancia formal, responde a la perfección en contenidos. De acuerdo con ello, no habria que ver tanto estos dos libros como una solución o colocación socorrida de un libro anterior sino como una auténtica y efectiva ilustración de la obra en la que se ubican. Así, en el capítulo 13 del libro VIll: De l'home, el más importante del Llibre de meravelles (la II cita del cuadro), Félix se maravillaría de estos varones, fulminando su denuncia y reprimenda, al igual que antes les había indicado - dedicándoles un capitulo- lo que tienen que hacer: actuar según sus posibilidades, de acuerdo con la naturaleza; pues el utilizar todos los recursos es la gran idea subterránea del Llibre de les bèsties ${ }^{14}$.

${ }^{10}$ La disyunción que estamos abriendo no desentona de la que experimenta en la llamada tentación de Génova, en que se ve dramáticamente obligado a optar, en un sueño, entre dominicos y franciscanos; pues, aunque sus simpatías estén con éstos, son los primeros los que le aseguran la salvación.

11 Rubió, en el prólogo a una edición de 1947, reproducida como estudio introductorio en la de 1985 en la colección «El Garbell" (Barcelona, ed. 62), se refería ya a "la soldadura un poc forçada" (ed. cit., pág. 13). Sin embargo, esta revisión del pasaje puede explicar expresiones de Félix, extrañado porque estos hombres hubieran conseguido tan alta orden: "Molt se meravella Fèlix dels dos homens com havien empetrat tan alt orde com és cell dels apóstols" (ed. cit., pág. 113), pues su admiración puede ser positiva o negativa; es decii, queda claro que Llull alaba la orden y el significado, pero no sus miembros.

12 Aunque normalmente se denominan novelas por su carácter narrativo, hay que hacer constar que no lo son en rigor desde el punto de vista del género, pues - en lengua romance y en prosa- no se conciben como tales hasta la novela caballeresca (el Curial e Güelfa y el Tirant lo Blanch), la cual cumple con los requisitos necesarios -el realismo literario, entre otros- para recibir la calificación del género moderno, que seguidamente y en la misma línea temática de la caballería consagraria el Quijote.

${ }^{13}$ Que el l.hibre d'amic e Amat tiene entidad por si mismo lo avala el que se haya editado y traducido independientemente (al alemán, español, francés, húngaro, inglés, italiano, latín); lo mismo que ha ocurrido con el Llibre de les bèsties (alemán, español, frarcés, inglés, italiano, japonés, portugués, ruso; hay una última edición, bilingüe catalano-castellana en ed. Eneida, "Bestiarios", Madrid 2003).

${ }_{14}$ Obsérvese que la única actividad de los personajes apostólicos en la obra es la de informar a Félix de un suceso que les parece de relieve - la elección del rey de los animales-, a la vez que ellos se evaden del lugar. En cuanto a Llull, no es extraño, sino que se corresponde con su extrema originalidad que reprenda a estos predicadores nómadas, que se caracterizaban por la abstención de todo compromiso y trabajo, a través de unos animales que se implican en los hechos sociales con todos los medios a su alcance y actúan febrilmente ejercitando las cualidades que les dio la naturaleza. 
Este planteamiento hace pasar a los hombres apostólicos a un lugar primordial, no como excusa sino como factor relevante, al que puede ir dirigido muy especialmente el Llibre de les bèsties y para quienes sería muy directo el ejemplo de estos animales. Hay que tener presente que se acusaba a esta secta de decir y no hacer (Batllori 1993: 166 y nota 5), mientras que no hay texto luliano más trepidante que éste; con ello cobraria pleno sentido su efímera pero destacada aparición.

En rigor, la cita inicial del libro (I del cuadro) no los alaba como individuos sino a la vida que representan, la de los apóstoles ${ }^{15}$ : Llull distingue finamente las vertientes a causa del origen de la tan digna denominación de la orden, pues dice Félix que el apostólico es superior a todas las órdenes, a la vez que afirma que un miembro suyo "no deu cessar de pregar e de fer bones obres a tot son poder»; a continuación, ellos dicen que no son dignos de tan alta vida, pues sólo la representan, pero tienen la esperanza de que Dios envie a la tierra representantes auténticos y, a ese fin, y para que los cristianos deseen su llegada, ellos representan a los apóstoles. En congruencia con lo dicho, Félix y los dos hombres, lloran largo rato orando según ese deseo. Actitud que se asemeja a la del pasaje en que los menciona de nuevo, reconocido como crítico (II), y en el que Félix y un ermitaño se exclaman anhelando una verdadera vida apostólica. Así como se parece también al de su tan sincero poema autobiográfico Lo desconhort, en que Ramón y el ermitaño piden a Dios que mande al mundo hombres valientes para mostrar la verdad de la fe. Visto así, no es una soldadura descuidada, sino ingeniosa, congruente hacia la misma obra y para con otras lulianas.

Este nuevo planteamiento se puede ratificar en el texto del Llibre de les bèsties. En primer lugar, en todo el capítulo $V$, que describe la actuación de los embajadores del León, pues se explica ahi con pormenores lo que significa representar a alguien, lo cual consiste en actuar en orden a su objetivo; así, esos embajadores animales - que son buenos representantes a pesar de emplear medios dudosos, como el soborno - van a erigirse en conciencia crítica del deplorable estado del reino de los humanos. Además, en el mismo capítulo interfieren, como verdaderos representantes activos, ocho prohombres que denuncian ante el rey el mal gobierno y atropellos de sus oficiales. Por todo ello, hasta tal punto puede constituir este capítulo una alusión a los apostólicos que se reconocen situaciones reproducidas o miméticas con el prólogo: los mensajeros llegan a una ciudad "on lo rei tenia gran parlament" (ed. cit., pág. 129), con lo cual esta última convocatoria sería réplica de la que había tenido lugar en el reino animal; asimismo, el rezo final de Félix y los apostólicos tendría su reflejo en el consejo del Leopardo a los prohombres irritados para que confíen en que Dios les enviará hombres buenos.

15 Cabe comentar, en referencia al hecho de la representación, que el rey de los hombres inflige una ofensa al León, rey de los animales, por menospreciar al Gato que le había enviado como presente, ya que como felino significaba y recordaba su persona (ed. cit., pág. 131). 
La espiral, a la que es tan dado Llull, está clara: los apostólicos deben representar a los apóstoles, como éstos representan a Dios; al igual que el Leopardo y la Pantera representan al León ${ }^{16}$. Hay un claro paralelismo: los animales son a éste lo que los humanos a Dios.

También se desprende el carácter de crítica hacia la secta en uno de los primeros ejemplos del capítulo IV, en el que Na Renard narra que un obispo no vivía según la regla y la doctrina que Jesucristo dio a los apóstoles y a sus descendientes ${ }^{17}$. Y se exhorta en los ejemplos siguientes a la vida activa, por encima de la retirada, cosa que hay que poner de lado a la postura de los apostólicos en el prólogo, los cuales se limitan a orar, pero se zafan de la elección del rey de los animales, que sin embargo interesa tanto a Félix. Y gracias a la cual Llull va a adoctrinar sobre el apostolado, aprovechando o echando mano precisamente de elementos insólitos: los animales.

Destaca este libro del panorama de libros de animales y bestiarios de la Romania, puesto que los ejemplos lulianos no guardan relación con la tradición animalistica occidental (Martin, L., 1996: 256). Asi, a pesar de la influencia vaga - pero indiscutible hasta en el nombre de la protagonista: Na Renart ${ }^{18}$ - del Roman de Renard ${ }^{19}$, predomina la cultura oriental -sobre todo a través del Calila i Dimna-, la cual le llega a Llull principalmente a través del esclavo que se compró a fin de acercarse al mundo árabe. También, visto de un modo más amplio, cabe considerar que esta inspiración proceda de su afán de apertura cultural ${ }^{20}$, que le lleva a impregnarse en profundidad de la sabiduría descendiente de Esopo y $\mathrm{Fe}$ dro, la cual puebla por lo general sólo como mero recurso los repertorios de ejemplos del dominio cultural greco-latino ${ }^{21}$.

${ }^{16}$ La lectura del capitulo en paralelo con el prólogo afecta desde el primer ejemplo del Leopardo, que sería crítico hacia los apostólicos, ya que muestra como se propaga el vicio al ejercerse públicamente -en este caso, la prostitución-, a causa de la permisividad y la pasividad.

17 "En una ciutat havia un bisbe qui era molt contrari a son ofici, e per la malicia e la deshonestat del bisbe, e per lo mal eximpli que donava a son capitol e a les gents d'aquella ciutat, se seguia molt de mal, e es perdia molt de bé que fóra en aquella ciutat si el bisbe fos aquell que ésser degra, segons la regla e la doctrina que Jesucrist ne donà als apóstols e a sos consegüents" (ed. cit., pág. 121). Es, pues, un continuum.

18 Frente al francés, Llull hace femenino al personaje del zorro, dado que en catalán - -tanto en autores de esta época como incluso alguna vez en la misma obra - las distintas denominaciones de este animal tienen género femenino: la volp, la guilla, la guineu.

ig La ascendencia de la obra francesa y del libro catalán en su época cobra especial interés a la luz de unos murales de Alcañiz, contemporáneos o poco posteriores a Llull, en los que aparecen un león, un gallo y un lobo, personajes destacados de ambos textos; por lo que se abre la pregunta: ¿a cuál de ellos remiten sus figuras? (RIOUER, M., Historia de la Literatura Catalana,I, Barcelona, ed. Ariel, 1964, págs. 306-307).

${ }^{20}$ La obra en que asienta esta actitud de comunicación como doctrina es el Llibre del gentil e los tres savis, que concluye sin pronunciarse acerca de la superioridad de ninguna religión a fin de quedar emplazados los sabios a seguir dialogando y discutiendo diariamente (BUTINÁ, J., "No busquem Llull entre els savis", Revista de l'Alguer, 6, l'Alguer, 1995, págs. 215-228)

21 Aportamos un comentario de M. Morreale: "Lo que ha asegurado popularidad a las fábulas esópicas durante tantos siglos es su contenido esencial y su artimaña; pero he querido sugerir que la veste que les dio cada autor está todavia por investigar en muchos puntos" ("La iábula en la Edad Media: el Libro de Juan Ruiz como representante castellano del Isopete", en "Y asi dijo la zorra". La tradición fabulistica en los pueblos del Mediterráneo, Madrid-Málaga, ed. Clásicas \& Charta Antiqua, 2002, pág. 238). 
Pero las fuentes, a pesar de su fuerte influjo, no determinan de modo exclusivo la impronta tan particular de esta obra; es decir, están tan absorbidas - hechas suyas, en una palabra-que no sólo cuesta reconocerlas sino que forman parte del tejido textual. Hasta el punto que su principal gracia literaria radica en esa personalísima confección, en el cosido ${ }^{22}$; y en esta obra sobre todo, en la que brilla más su talento literario, se ha llegado a advertir que "l'estil és l'home" (Bohigas, P.,1982: 52) ${ }^{23}$.

La obra en conjunto se suele decir que trata de la elección del señor de los animales, pero en realidad desde el capítulo Il trata de la sujeción a esa señoria: en el 1 (De l'elecció del rel) se elige al León, mediando las argucias de Na Renard, a pesar de revelarse sus intereses espúreos para hacer predominar los intereses de los carnívoros sobre los de los herbívoros ${ }^{24}$; pero en los tres siguientes se reflejan las maniobras de Na Renard, que ha quedado fuera del Consejo real, para medrar (II: Del consell del rei; III: De la traíció que Na Renard tractà del rei; IV: En qual manera Na Renard fo porter del rel) ${ }^{25}$, de modo que pacta con el Elefante a fin de traicionar al León o consigue manipular al Buey para infiltrarse ambos en círculos próximos al regio felino ${ }^{26}$.

En el V (Dels missatgers que el Lleó tramès al rei dels hòmens), tiene lugar la mencionada embajada del Leopardo y la Pantera al reino de los hombres, por indicación del Buey, quien los conoce bien por haber sido su animal doméstico. En el VI (De la batalla del Leopard e de l'Onça) luchan el Leopardo, ultrajado en su honor al haber abusado el rey de su esposa en su ausencia, y la Pantera, que representa al León ${ }^{27}$. En el último capítulo (De la mort de Na Renard), ésta se ve desenmas-

Ocurre asimismo con otro libro de animales, la Disputa de lase (ca. 1418) del fraile renegado Anselm Turmeda, que, a pesar de seguir textos árabes, deviene una obra nueva gracias a su ejecución literaria.

2.3 Este rasgo, que individualiza a este autor y afecta a sus fuentes, va de la mano con que éstas no ejerzan una finalidad retórica; es sabido que Llull es un gran autor sin quererlo, pues él en realidad lo que pretende es convertir a los hombres por todos los medios, pero, a costa de conseguir una alta efectividad moral, su obra supera la de autores que se afanan sólo por un efecto artístico. Estilo el suyo próximo al de los partidarios de la oscuridad, dado que los contenidos no son accesibles a simple vista.

'24 Merece resaltarse el humor del final de este primer capítulo, en que se narran las peripecias del Caballo y del Buey quienes, ante las consecuencias de la elección - pues el Consejo real, que se alimenta de animales, se ha comido a sus hijos, un pollino y un ternero-, se marchan a servir al hombre. Tema además que ya nos alerta acerca de la temática alrededor de las fidelidades.

25 A raiz de la queja de Na Renard, según la cual, a ejemplo de la humildad evangélica, debia haberse contado con consejeros más simples -evidentemente pensando en su propio tamaño frente a los elegidos: el Oso, el Leopardo, la Pantera, la Serpiente y el Lobo-, el Consejo - también asesorado por ella-decide ampliarse con herbivoros de buena presencia (el Elefante, el Jabalí, el Macho cabrío y el Cordero); ahora bien, en última instancia falla en su intento por ser consejera, pues la extensión al Gallo - ejemplo de sumisión para la reina- excluye a Na Renard al ser antitético con ella (ed. cit., págs. 117-118).

26 El principal merito literario consiste en esta habilisima sucesión de intrigas que va trenzándose por medio de ejemplos - de humanos en boca de los animales y viceversa-, a veces encadenados o con motivos que los enlazan; los cinco que expone Na Renard para que el Elefante acceda a prestarse a ser rey son un prodigio de habilidad dialéctica (ed. cit., págs. 119-120).

27 Esta lucha $-y$, por consiguiente, este capitulo- dejan constancia de lo malvado e inmoral que es el León, que no sólo ultraja a un súbdito mientras actuaba de embajador suyo, sino que su actuación tras la batalla burla todo principio de justicia, ya que a pesar de haber ganado el Leopardo, no puede aguantar el deshonor de la derrota de quien le representa a él -la Pantera- y se aprovecha del cansancio del contrincante y vencedor para matar impunemente a aquél (ed. cit., págs. 135-137). 
carada por los otros animales, que han aprendido de su hasta entonces invencible astucia.

Pero de hecho, tras la supremacía del ingenio, que sería una primera lección práctica, subyace otra intimamente ligada: el poder que se asienta definitivamente es el del León y quedan relevados los animales que le son fieles ${ }^{28}$. Por lo tanto, desde la doctrina tradicional de la cristiandad, si es difícil la primera lección -la sagacidad a ultranza para lograr unos fines-, si se toma puntualmente la declaración final de ser el libro una moraleja para los gobernantes, desde algunos puntos de vista ineludibles, es todavia de más difícil lectura la segunda. Nos hallamos, pues, ante un gran apólogo, todo él una semblanza, con enfoque e intencionalidades muy pero que muy peculiares ${ }^{29}$.

Vamos a fijarnos también en la perspectiva sociopolitica, de especial interés para un ámbito histórico. El capítulo $V$, en que el León manda la mensajería al rey de los hombres, es donde concentra Llull la crítica social más abierta ${ }^{30}$. Ahora bien, aun siendo la más ácida del libro ${ }^{31}$, comparativamente es suave con la que suele afilar contra los malos eclesiásticos ${ }^{32}$; hecho que acentúa la posible crítica a los apostólicos.

Es valioso el retablo que con esa descripción deja respecto a su sociedad ${ }^{33}$, además de estar bien fundado en aspectos como el del mundo juglaresco, que conocía bien Llull cuando antes de su conversión era un cortesano que componía poemas trovadorescos. Pero por mucho que nos matice los ideales lulianos y sea de utilidad para perfilarlos, queda claro siempre que su visión es netamente me-

28 No hay que olvidar que el León es injusto y despótico, como subraya el narrador al aparecer dando una aclaración moral a continuación de la batalla, pues señala que a consecuencia de su mala acción ha perdido facultades: "Lo Lleo, depuis que fo en pecat e hac mort lo Lleopard, no hac tanta de subtilesa ni engin com d'abans havia. e no entès ço que les paraules que la Serpent hac dites significaven", ed. cit., pág. 138. (Que la maidad enturbia el intelecto también se verá en Dante, como manifiesta el inicio del Convivio; asi como aparece en otras obras lulianas: "per la mala volentat es torbat l'enteniment a entendre", Llibre del gentil e los tres savis, en Obres essencials, Barcelona, ed. Selecta, 1957, pág. 46).

29 Sobre ésta y sobre el relieve del Llibre de les bèsties, a la luz de otra fuente que aporté en 1996 para el Libre del gentil (el Libro de Job) y que extendia a esta obra, recojo parecidas conclusiones a las que llego en este trabajo: "era el tema que Déu posava a Job com a enigmàtic i dificil d'explicar: la gran intel.ligència que mostren els animals. Si això és aixi, tot el Llibre de meravelles pot girar a l'entorn del L/ibre de les besties i no ser pas aquest un afegit redactat a part, com s'ha cregut generalment" ("El cor del Llibre de meravelles lul lià", Revista de Filologia Románica, 13, Madrid, Universidad Complutense, pág. 99).

30 Toda la crítica coincide en reconocerle en el hombre de gran barba y pobres vestidos que interviene para condenar las deshonestas funciones de los juglares (ed. cit., pág. 131), de un modo similar a cómo, en el Blanquerna, «Ramon lo foll» acusa a toda la curia pontificia (capitulo 79).

31 Merece destacarse alguna trase: "la pus mala bestia e la pus falsa qui sia en est món, és hom (...) dhom mal, poderós, e maestre, nulla bèstia no es pot defendre", ed. cit., págs. 126, 127.

32 Uno de los ataques más duros se proyecta sobre el clérigc que discute con él en su último diálogo, el Phantasticus o la Disputa del clergue Pere i de Ramon el fantàstic (traducido al catalán en L. BADIA, Teoria i pràctica de la Literatura en Ramon Llull. Barcelona, ed. Quaderns Crema, 1992. págs. 211-229).

3.3 En la introducción a la edición de "El Garbell" se reproduce de una edición anterior de Llinarès (1964) un extracto que trata de la sociedad religiosa, la sociedad politica y los principios morales del libro (ed. cit. págs. 25-31); también. P. Bohigas, se refiere a los ideales de la epoca (1982: 54-55). 
dieval ${ }^{34}$ y que no aspira a otro orden que el feudal ${ }^{35}$. Por otro lado, con este análisis ocurre como con el pretender concretar el príncipe al que va dirigida la obra, según consta al final del libro ${ }^{36}$, que, aunque son datos valiosos no constituyen ni explican su finalidad. Son datos de interés, pero no pasan de ahí; pues Llull es un hombre práctico, pero ante todo es un filósofo.

De todos modos, su medievalismo no es drástico; valga aquí la aguda definición batlloriana de Llull como escolástico independiente o atípico, por no compartir el método didáctico ni el argumentativo (Batllori, M., 1995: 41). Vamos a observar esa doble faceta en un pasaje que afecta a un caso típicamente medievalizante, el relativo al juicio divino. Pues bien, en la batalla ya citada entre el Leopardo y la Pantera se comienza definiendo éste y su fundamento ${ }^{37}$, pero durante el curso de la lucha se nos da la causa racionalista para la victoria del primero ${ }^{38}$. Y aún más, al final del pasaje —o sea, de hecho, a consecuencia de la

34 Aunque le separen pocos años de Eiximenis, las ideas sociopolíticas de ambos difieren notablemente. Las de este franciscano han sido estudiadas atentamente por José Luis Martín, en "El tratado de caballeria de Francesc Eiximenis", Norba. Revista de Historia 16. Universidad de Extremadura, págs. 295-331, y La mujer y el caballero. Estudio y traducción de los textos de Francesc Eiximenis, ed. Universidad de Barcelona, ambos de 2003; “Hermes Trismegisto revisado por Francesc Eiximenis", en Tradición clásica. Homenaje al Profesor Gaspar Morocho Gayo, págs. 721-728, y «Eiximenis: un enciclopedista de la Edad Media", La aventura de la Historia, 64, 2004, págs. 76-81. Asimismo, este ángulo eiximeniano ha sido atendido recientemente desde la filosofía ( $A$. Uña, en «Moral y moralidad en la gestión pública", Cuadernos Salmantinos de Filosofia, XXII, 1995, págs. 51-68).

35 Lo deja manifiesto al recomendar varias veces seguir con el señor conocido y sobre todo al establecer la primacia de la fidelidad; este rasgo se asegura bien en el desenlace, puesto que el Elefante, al denunciar al rey la traición fraguada con Na Renard y pedirle perdón arrepentido, arguye que prefiere ser leal sometido que traidor rey. Baste, por último, recordar el final, en que se previene al rey que debe guardarse de los hombres falsos que pueden subvertir su orden. $Y$ una prueba definitiva de la ausencia de los valores modernos de rebeldía o insurrección se puede apreciar en la nula reacción de los animales ante el comportamiento injusto de su rey al matar al triunfador de una batalla: todos expresan que desearian tener a otro por señor; pero la indignación se queda en un mero comentario (ed. cit., pág. 137). En definitiva, no se trastoca el poder jerárquico.

36 Llinarès, en la introducción citada, a pesar de advertir que puede referirse a alguien imaginario, propone a Felipe el Bello, rey de Francia, que aparece en otro pasaje del Llibre de meravelles (libro VIII. capitulo 46, ed. cit., pág. 263). A mi entender, no interesa tanto atender a su personalización como a los contenidos morales del libro, que podrían contribuir a descifrar la misma dedicatoria o bien a hacerla secundaria o diferenciada (¿podría acaso tratarse de un principe de la lglesia?).

Téngase en cuenta también que la direccionalidad a los apostólicos no se contradice con esta dedicatoria, como puede ejemplificar el capítulo 4, en que los ejemplos que ponen la Serpiente y Na Renard se dirigen al rey, de quien dependerán las consecuencias de su conversación, pero el hilo conductor está entre ellas dos, que se están contestando entre si: la segunda está celosa por no pertenecer al Consejo reał como aquélla, por lo que, tras poner Na Renard un ejemplo pernicioso para la Serpiente, ésta replica con otro en que un martín pescador, creyéndose muy listo, de hecho se provoca la muerte; la respuesta de $\mathrm{Na}$ Renard es fulminante, alegando la maldición biblica a su especie, cosa que no puede ser esquivada por la Serpiente, cayendo en desgracia ante el rey, quien la expulsa de su Consejo.

37 "Batalla to atrobada per ço que veritat confusés e destrovis falsia. Déus és veritat; per què tota persona qui mantenga falsedat, se combat ab Déu e ab veritat” (ed. cit., pág. 136), según dice en secreto la Serpiente.

38 Queda bien especificado que la Pantera - que habia alcanzado a oir las palabras secretas de la Serpiente (nota anterior) - estaba disminuida puesto que la conciencia le remordia, mientras que al Leopardo le animaba la ira contra el rey; es decir, sin mentarse la te religiosa, se nos está aportando la explicación racional del curso del evento: "Tant era forts lo Lleopard, per l'esperança que havia en son bon dret, que no li era semblant que per res pogués ésser vençut", ed. cit., págs. 136-137. 
batalla - no se cumple la victoria del mantenedor de la verdad, dado que, como hemos visto, al no poder soportarlo, el León mata al vencedor; luego, si el Leopardo muere de resultas de esa batalla, no se lleva a término o no se realiza el juicio divino ${ }^{39}$.

En cualquier caso no hay que perder de vista que Llull a quien ataca es a la sociedad humana, dado que con ambiciosa finalidad, por encima de la concreta audiencia de su tiempo, pretende una utilidad más general ${ }^{40}$. Nos hallamos ante la sátira de un autor que por antonomasia es un apóstol, por lo que embiste especialmente a los cristianos, a pesar del innegable aprovechamiento político de los coetáneos $^{41}$; por tanto, lo que está haciendo una vez más es intentar sacudir a éstos - probablemente en especial a los apostólicos_, impresionándoles a fin de darles vigor, valentía y autenticidad, sacándoles del letargo y corrigiendo su inercia al dejarles por debajo de los irracionales si no salen de su inacción e indisciplina. Esto no era la primera vez que ocurría en la literatura ${ }^{42}$, pero resulta chocante por parte de un adoctrinador de fuerte signo cristiano y del modo que to hace Llull. Porque no sólo no pone de ejemplo a santos, sino que, así como en el Llibre del gentil e los tres savis ponía como modélico el comportamiento de un gentil (Butiñá, J., 1997: 84) y en el Blanquerna la mística sufí, a fin de que aprendan ciertos religiosos, aquí les pondría los brutos por delante. La ejemplaridad de los animales se constata en el libro VIII, dedicado al hombre: «gran meravella és aquesta: que les criatures qui no han raó, seguesquen l'entenció per què són creades, e que hom, qui ha raó, no la seguesca”, (ed. cit. pág. 311).

39 Por ello, no participamos del comentario que se da en la nota 13 (ed. cit. de 1985, pág. 85), en cuanto a que en este punto Llull no se avanzó a su tiempo, puesto que el afán por dar la razón científica le hace despegarse del criterio exclusivamente de fe que sella de modo impermeable y caracteristico aquel juicio, así como el final adverso permite poner en duda que lo defendiera o estuviera convencido de ello. Esto es imnortante para el hilo de este articulo porque, aqui también, estamos proponiendo leer el pasaje desde otro ángulo: que muestre la firme creencia en la revelación de la verdad no implica que la victoria sea del que la mantiene. El realismo de Llull, que sabe que no vence el bien en el mundo, hace de ello una constante y da explicaciones contundentes de esa inversión, fundadas en la maldad de los hombres. Dejaba ya muy claro en el episodio final del Libre del gentil e los tres savis que la maldad triunfa porque los hombres "son amadors dels bens temporals, e tebeament e ab pocca devoció amen Deu e lur pruixme, per asó no an cura de destruir ffalssetat e error" (Llibre del gentil e los tres savis, op. cit. pàg. 208).

40 Según A. Vega, el Llibre de les bèsties le sirve a Llull "para poner de manifiesto la crisis moral de la sociedad" (Ramón Llull y el secreto de la vida, Madrid, ed. Siruela, 2002: 129) y según L. Badia, el de Meravelles es "una enciclopedia popular encubierta bajo el cuento del joven Félix que recorre el mundo asombrándose de todas las perversiones de la primera intención" ("La ficción luliana en los origenes de las letras catalanas", en Constantes y fragmentos del pensamiento luliano. Actas del simposio sobre Ramon Llull en Trujillo, 1994, ed. de F. DOMinguez y J. DE SALAS, Sonderdruck aus Beiheft zur Iberoromania, 12, Tübingen, 1996, pág. 68).

4) No hay que renunciar al aspecto de manual de sabiduría política reconocido tradicionalmente. En el seminario que di sobre este libro en el Centro Cultural Blanquerna de Madrid: El "Llibre de les bèsties" de Ramón Llull: las bestias como modelo, el 2 de noviembre de 2004, fecha de las ultimas elecciones norteamericanas, comentamos que ni incluso ante la complejidad de este acontecimiento desmerecía el libro luliano en vigencia, pues su fina y alta política o la malicia inteligentemente empleada no se veían disminuidas frente a la realidad o argucias de ocho siglos después.

4. Es un rasgo común de la filosofía antigua, preferentemente de los cínicos. 
Se hace obvio que no se está estableciendo la moralidad que marcan las bestias en tanto en cuanto éstas se manifiestan en su comportamiento irracional y natural -completamente vil desde la moralidad humana-, pero ello no obsta a que figuren como ejemplares; es decir, Llull no puede sugerir el encumbrar la egoísta ley de la selva, ni siquiera en atención al fin práctico de que el gobernante no se deje engañar. Ni puede perseguir sólo que los príncipes aprendan de este tremendo caudal de engaño y maldad, ni tampoco establecer que al fin y al cabo vence el más poderoso e inmoral; sin embargo, no hay vuelta de hoja: se lo dedica a un príncipe y, si hay que aprender de la narración, el ganador es el inmoralísimo León. Y es ahí, en la pregunta profunda, donde esta obra es altamente chocante e intrigante, al margen de las notas que la hacen curiosa o llamativa; e -insisto- es cuando sorprende que, por mucho que se base en fuentes orientales, no haya sorprendido más tamaña inmoralidad, aunque fuera tan sólo en apariencia. Pero es también ahí donde nos vemos obligados a desentrañar su vena satírica ${ }^{43} y$ donde pueden hallarse fecundas explicaciones, puesto que la fidelidad al señor que Llull estaria ilustrando seria la jerárquica, a la que necesitaba imperiosamente someterse aquella secta; recomendación que hace al amparo del símil feudal ${ }^{44}$.

Los animales no tienen sentido moral ${ }^{45}$ por lo que, en su reino, domina la ley del engaño y el poder malsano e interesado; pero toda la obra se apoya o aprovecha esta rotunda inmoralidad, de modo que el comportamiento maléfico de $\mathrm{Na}$ Renard emula al arrebato y la sinrazón, que caracterizan al León. $Y$ de todo ello se sirve el autor ${ }^{46}$.

Pues nos transmite que, ingeniosamente, hay que saber aprovecharse de todos los medios al alcance, cosa que hacen estos animales con un modus operan-

43 «En els restants tractats, l'essencial era la doctrina, les faules n'eren només una confirmació i un complement. Aci, per contra, la faula forma la trama essencial del llibre; la moral s'hi veu tan sols apuntada" (BATLLoRI, M., 1993: 168). La sátira, pues, no se dirige a personas inmorales sino, en buena logica, a personas inactivas y faltas de fidelidad, carentes de lo que asienta la fábula.

44 También podría haber protagonizado el libro el León mostrando la importancia del miedo a la fuer. za, pero el enfoque desde Na Renard no sólo se beneficia de la moda del personaje sino que desarrolla mejor el aspecto recientemente comentado de aprovechar todos los medios, que permite un golpe de efecto: la astuta zorra es vencida gracias a la astucia y. en última instancia, sólo los fieles quedan en buen lugar.

45 Aunque en ocasiones, en las que quizás supongan un reproche a los humanos, manifiestan sentimientos; asi ocurre con el Leopardo cuando se alegra de que su esposa hiciera el adulterio forzadamente, lo cual aumentó su ira ("car si en fos pagada, no n'hagra tant de desplaser», ed. cit., pág. 135), al final del capitulo 5, pues se opone rotundamente al sentimiento de ira injustificada del burgués, al principio del mismo capitulo, que se encoleriza por el adulterio de su mujer cuando él mismo habia sido la ocasion.

46 Como ejemplo del aprovechar la acción de los otros, en el mismo Llibre se expone el ejemplo del cuervo que hacia su nido en la roca y una serpiente se le comia los polluelos. El cuervo modélico, como no era tan poderoso como el reptil, se ve obligado a recurrir a las malas artes; por lo que, un buen dia, en que la hija del rey jugaba en un vergel y deposita su diadema en una rama, aquél se la coge y se la lleva volando, depositandola donde estaba la serpiente. A la vista del disgusto de la princesa, los servidores reales siguen al cuervo y, al hallarla junto a la serpiente, son ellos los que la matan, a fin de recuperarla. “Enaixi, lo corb ajudà's ab altres, de la serpent, per art e per maestria" (ed. cit., pág. 124). 
di que abre un abanico, de las posiciones maquiavélicas al David de Bernini, en el Palacio Borghese. Encuadre que permite resaltar la faceta del Llull reformador y explica que, a pesar de la envoltura escolástica, su figura reaparezca e interese en el Humanismo renacentista.

Un análisis simple del libro nos lleva a entender que el hombre puede aprender de los animales, que usan espléndidamente de sus facultades de acuerdo con sus cualidades naturales ${ }^{47}$; y esto lo extrae del bagaje oriental y occidental, en una peculiar hibridación cultural. Utilizan, por tanto, para sus fines las dotes de que disponen, la fuerza bruta o la sagacidad, puesto que cumplen su misión según la ley natural ${ }^{48}$. En una palabra, responden al orden en el que han sido creados $^{49}$. Veamos las primeras palabras de la tan lista $\mathrm{Na}$ Renard al irrumpir en la escena de la elección del rey de los animales:

"-Senyors - dix Na Renard-, con Déus creà lo món, no el creà per entenció que hom fos conegut ne amat, ans ho féu per ço que ell fos amat e conegut per hom; e segons aital entenció, Déus volc que hom fos servit per les bèsties, jatsia que hom viva de carn e d'herbes (...) devets seguir la regla e l'ordonança que Déus ha donades e posades en les creatures" (Ed. Cit., pág. 114).

Advierte, pues, Na Renard que no han de seguir sus intereses - como herbivoros o carnívoros-, aunque se vean perjudicados, sino los intereses de Dios. Con este planteamiento, de acuerdo con la propuesta inicial referente a los apostólicos, no estamos alterando la cronología de esta obra - que, se mire por donde se mire, es independiente y anterior-, pero si alteramos la concepción de Llull, que en un punto tan álgido, como es la inserción de este libro, no pudo haber dejado un gazapo; al contrario, encierra un sentido muy agudo que incide de modo coherente con la obra en que se integra: en el refuerzo de la primera intención cara a aquellos hombres, que deben implicarse y no quedarse pasivamente al margen.

Todo esto nos ofrece la imagen de un Llull hábil y socarrón, a la vez que fiel pero independiente frente a la ortodoxia más recalcitrante ${ }^{50}$; imagen que responde fielmente al principio de la obra, en que dijimos que el padre de Félix se sorprende de que el hombre pueda alterar el orden de la Creación, que - como suscribe $\mathrm{Na}$ Renard- tan bien cumplen los animales. $Y$ si es escándalo tan grande que las

L. Badia, recordando a Robert Pring-Mill, comenta que «lo que resulta realmente asombroso, desde la perspectiva del estudio de las formas literarias, es que Llull sea capaz de contar cuentos declaradamente científicos: la ficción natural de Llull es una de sus rarezas más geniales», op. cit., 1996, pág. 68 .

4 P. Villalba observa que Llull parece recoger los postulados de la naturaleza próximos a Cicerón, en "Reminiscencias ciceronianas en Ramón Llull", http://www.hottopos.com/convenit7/villalba.htm

45 Hay que valorar la originalidad de haber creado una estética comprometida, pues bajo "un variadissim ventall de formes estilistiques i literàries externes, sàviament destinades a fer atractiu el seu missatge, hi trobem sempre la impressionant univocitat d'una crida constant a la primera intenció" (HAUF, A.. "Les veus del temps. Llull, o l'estètica compromesa". Estudis Baleàrics, 72-73, 2002, pág. 239).

50 La actitud hacia los apostólicos - a los que adoctrina y reprende en esta obra. con advertencias primero y con vituperio después- es afin con la que mantiene con los pecadores, herejes y gentes de otras ideologias, bajando a la arena a discutir con ellos; cosa que era ilicita aun para teólogos posteriores a él. 
criaturas que tienen razón no sigan la ordenación de la Creación ${ }^{51}$, no digamos los eclesiásticos; y aún más los apostólicos. Desde esta perspectiva, en efecto, los hombres han de aprender de los irracionales; los animales devienen, así sí, un ejemplo didáctico ${ }^{52}$.

Un pasaje del gran e insigne humanista de las letras catalanas, Bernat Metge, puede mostrar que anduvo cerca de entenderlo ${ }^{53}$. Asi como lo debió entender Ramón Sibiuda ${ }^{54}$, filósofo prerrenacentista cuya obra El libro de las criaturas está impregnada de lulismo - aun sin citar a Llull-; asimismo, recoge la idea el ensayo 12 del libro II de Montaigne, en que se traduce prácticamente a Sibiuda, haciendo resonar las ideas lulianas por Europa, pero también sin citarlo. $Y$ otro humanista, san Ignacio de Loyola, hace de la primera intención uno de los puntales de su renovadora congregación.

Luego, sin pretender hacer a Llull más moderno de lo que es ni descolocarlo de su época, en ciertos aspectos ${ }^{55}$, como el «naturalismo» que explica en profundidad el Llibre de les bèsties, anticipa actitudes modernas que iban a entender los humanistas ${ }^{56}$. Y aunque no es nueva ni inédita la idea de que Llull esté detrás de los orígenes del Humanismo, sí lo es el aplicarlo para la lectura de esta obra, acentuando el carácter crítico desde la sátira al mundo clerical disidente. El momento histórico de Llull es profundamente medieval, e incluso, una cúspide, pero desde ella se anticipan visiones posteriores.

Haremos un par de reflexiones finales. Una, a raiz de recordar que Llull es uno de los autores de más acendrado cristianismo; aunque no acostumbra a citar los Evangelios, no sólo representa a la perfección el ideal caritativo sino que no se

51 «Ve per lo món, e meravella't dels hòmens per què cessen d'amar e conèixer Déu», ed. cit., pág. 19. Así pues, lo que más sorprende a Félix es el mal, como capacidad de desordenar la Creación.

52 En cierta manera como en el Llibre del gentil, que está en la base de toda su obra, no le preocupa tanto dar nuevos argumentos apologéticos como propinar un sermón; no tanto hacer hombres doctos, como buenos. Para ello, se ve obligado a denunciar y ser crítico, tal como lo es en las apariciones en sus obras y tal como exhorta a los apostólicos, pues bien sabe que el defecto de los hombres es moral.

$53 \mathrm{He}$ apuntado ya la firme relación entre Llull y Metge. Pues bien, hay que recordar que en $L O$ somni, cerrando el libro I, se constata que el alma humana se diferencia de la animal sólo por la racionalidad y la ética, la cual garantiza la inmortalidad; los siguientes libros del diálogo se dedican a la moral; por tanto, los hombres que no siguen esa pauta quedan homologados a los animales. Es más, la razón que da Metge para la pervivencia del mal, a lo que se ha referido poco antes, procede del Llibre del gentil e los tres savis (J. BUTINA, En los origenes del Humanismo: Bernat Metge, UNED, Madrid 2002, págs. 211-213).

54 Véase El llibre de les criatures, trad. y ed. a cargo de J. de Puig i Oliver, Barcelona, ed. 62, 1992. Cabe recordar que Batllori se refiere a la filosofía natural extrateológica de Sibiuda (Obra completa, V, De IHumanisme i del Renaixement, pról. de E. DuRAN, Valencia, ed. Tres i Quatre, 1995: 20) o que para Curtius este autor "se propasó al decir que quienes falsifican el libro de la naturaleza son peores herejes que quienes tergiversan las Escrituras" (Literatura europea y Edad Media Latina, I, Fondo de Cultura Económica, Madrid $5^{\mathrm{a}}$ ed.19895 , pág. 449).

5.5 Entre otros factores, se han destacado también como favorables para su perduración el marcado racionalismo, la aspiración a la unidad de las ciencias o el arte combinatoria.

56 Llull fue desarraigado de Castilla a causa de la Inquisición (BuTiñ, J., Acerca del lulismo castellano, "A Distancia", UNED, otoño 1995, págs. 51-54); pero se rescata gracias a Cisneros, en el Renacimiento 
mueve un ápice de la doctrina que transmiten. No puede dejarse por tanto de lado el recuerdo evangélico de que hay que ser como los animales, en concreto como la serpiente y la paloma (Mateo 10, 16), en una difícil o muy completa recomendación. Para Lluil el ejercicio de sus cualidades es afín a la misión que se les ha encomendado al servicio de los hombres, ya que la onda del encargo evangélico recae en que éstos aprendan de aquéllos.

Con una última reflexión quiero resaltar el valor de las obras lulianas en lengua catalana (sólo 52 entre un total de casi 300), quizás las más puras por haber pasado muy desapercibidas, ya que al no ir dirigidas a teólogos han sido más impermeables a la Inquisición y se han deformado menos. Esta audiencia tan cercana, la que le leía en catalán, la concreta en el prólogo del Llibre del gentil e los tres savis, que alega haber escrito para los laicos ${ }^{57}$. Es decir, son textos que recogen fielmente sus ideas ${ }^{58}$; lo cual constituye un motivo más para insistir en extender las traducciones catalano-castellanas ${ }^{59}$.

\section{REFERENCIAS BIBLIOGRÁFICAS}

Batllort, M.: Obra completa, II. Ramon Llull i el lul.lisme, pról. de A. Hauf, Valencia, ed. Tres i Quatre, 1993.

BOHIGAS, P.: Introducció al "Llibre de les bèsties", en Aportació a l'estudi de la Literatura Catalana, Publicaciones de la Abadia de Montserrat 1982, págs. 49-56.

BUTiNÁ, J.: "Unes notes sobre Metge, Llull i Juvenal», en Homenatge a Miquel Batllori, 4, Randa, 51, Barcelona, ed. Curial, 2003, págs. $7-29$

ButıNA, J.: "Si Lucia fos Lulio", en Estudis de Llengua i Literatura en honor de Joan Veny, II, ed. de J. Massot, «Biblioteca de l'Abat Oliba», 190. Publicaciones de la Abadía de Montserrat, 1998, págs. 51-68.

ButiñA, J. (coord.): Ramon Llull, en Literatura Catalana, I, UNED, 1997, págs. 47-116.

Butiñ, J : "El diálogo de Bernat Metge con Ramon Llull. Dos nuevas fuentes tras Lo somni», en: Paredes, J. (ed.). Actas del $V$ Congreso de la Asociación Hispánica de Literatura Medieval: Medioevo y Literatura. Granada, 1995, págs. 429-444.

57 "Car rús façam aquest libre per als hòmens lecs", op. cit., pág. 1057. Precisamente el humanismo ofrecerá un caldo de cultivo para lectores de teologia entre el mundo laico de estas letras (véase mi trabajo Un par de notas sobre el humanismo catalán, en el Homenaje a $M{ }^{a}$ José López de Ayala, coord. por $\mathrm{J}$. Costas, UNED, en prensa).

58 Cabe observar, por ejemplo, que en ellas no aparecen condenas drásticas de otras religiones, de acuerdo con la filosofia del Llibre del gentil, su obra de cabecera; por lo que la actitud exageradamente cerrada y ortodoxa quizás se le ha ido añadiendo con el tiempo, al igual que ocurrió con la fama de alquimista o con otras adherencias medievales (véase mi trabajo en prensa "El diálogo en Llull y en Metge". Estudios Hispánicos, 12, Miscelánea de Literatura española y comparada. Homenaje a Roberto Mansberger Amorós, coord. por A. August ZaREBSKA, J. Butiñ, J. ZiaRkovSka, Universidad de Wrockaw).

54 La latinista Matilde Conde está preparando la edición y traducción de la edición francesa antigua. en latin, del Llibre del gentil e los tres savis. Asimismo, he preparado la traducción e introducción de El Libro de los animales para www.ivitra.ua.es. Una vez en prensa este trabajo, he localizado un dato que refuerza la propuesta presentada aqui respecto a que los espirituales o apostólicos fueran audiencia muy específica del Llibre de meravelles: se trata de que en 1289, fecha que se acostumbra a dar para la redacción de esta obra (Batllori 1993: 166-168), tuvo lugar un encuentro entre Llull y el nuevo ministro general de la orden franciscana, Ramón Jofré o Gaufred, encuentro que debio ser importante para el primero dado que le supuso tener que viajar a los Alpes, donde se hallaba éste. Y es significativo al respecto el carácter de Jofré, quien, “no era própiament un dels espirituals, però si un superior ben benigne amb aquests i més comprensiu tambe que els seus antecessors", Ramon Llull i l'espiritualisme joaquimític: 1290-1293, en Batllori 1993: 17. 
ButiñA, J.: "Metge, bon lul lista i admirador de Sant Agusti, Revista de Filologia Románica, 11-12, Madrid, Universidad Complutense, 1994-1995, págs. 149-170.

Dominguez Reboiras. F: Ramón Llull. I y li, en www. Liceus.com

Ltult, R.: Llibre de les bèsties, ed de J. Rubió-A. Llinarès, "El Garbell". 17. Barcelona. ed. 62, 1985.

LLULL, R.: Llibre d'Evast e Blanquerna, "MOLC" 82, Barcelona, ed 62, 1982.

LLULL, R.: Llibre de meravelles, "MOLC» 36, Barcelona, ed. 62, 1980.

LuBAC, H.: La posteridad espiritual de Joaquin de Fiore, I, De Joaquin a Schelling, Madrid, ed. Encuentro. 1989.

MARTIN. L.: La tradició animalistica en la literatura catalana medieval, Institut de Cultura Juan Gil-Albert, Generalitat Valenciana 1996.

Riouer, M. DE: Ramon Llull, en História de la Literatura Catalana, I, Barcelona, ed. Ariel, 1964, págs. 197352.

Rubio I Balaguer J.: Obra completa. Il, Ramon Llull i el lul lisme. Publicaciones de la Abadia de Montserrat, 1985. (Incluye el prólogo al Llibre de les bèsties de la edición independiente citada, págs. 315323). 